\title{
HÅNDSKRIFTENES HJEMKOMST - VITENSKAPELIG OG IDEOLOGISK BELYSNING
}

\section{Vésteinn Ólason}

Forutsetningen for håndskriftsaken er håndskriftene og den litteratur som de inneholder. Jeg synes det er nødvendig a konstatere at den islandske middelalderlitteraturen var rik og variert, og at det var en stor bokproduksjon her $i$ landet $i$ middelalderen, spesielt $p a$ 1300-tallet. Man begynte à skrive på morsmålet omkring 1100, men fra 1100-tallet har vi bevart bare noen fä händskriftfragmenter. Den mest originale del av litteraturen ble nok skrevet på 1200-tallet, og fra det ärhundre, spesielt den andre halvdelen, har vi noen fine händskrifter og mange fragmenter. Men de mest kjente og mest omfangsrike genrene, kongesagaer og islendingesagaer, er med meget fä unntak overlevert $i$ avskrifter fra 1300-tallet eller senere. I dette århundre ble det også produsert viktig ny litteratur, og de fleste av varre fineste membraner er fra den tiden. 1400-tallet var på mange màter en forfallsperiode her $i$ landet som i det øvrige Norden, og såvel litterar nyskaping som bokproduksjon minsket i omfang og kvalitet.

Jeg har lyst til å nevne noen få viktige bøker som eksempler: Fra omkring 1200 har vi den islandske homilieboken, Perg 15 4to i Kungliga biblioteket i Stockholm. Fra andre halvdel av 1200-tallet har vi Codex regius av eddadiktene, GKS 2365 4to, to lovbøker med de gamle fristatslovene, Konungsbók, Codex regius, GKS 1157 fol, og Stadarhólsbók, AM 334 fol. Fra 1300-tallet skal jeg bare nevne fire: Mödruvallabók, AM 132 fol med 11 islendingesagaer (gjerne de beste tekstene som finnes av disse sagaene), Stjórn, AM $227 \mathrm{fol}$ med en oversettelse av store deler av det gam- le testamente, Skardsbók Jónsbókar, AM 350 fol og Flateyjarbók, GKS 1005 fol. Fra 1500tallet har vi også en del illustrerte lovbøker.

Hvor mange håndskrifter var det da som feiden angikk?

Det er ikke en enkel sak å telle håndskrifter. De registreres som numre, men to blad som opprinnelig har tilhørt den samme codex kan være registrert på forskjellige numre. Noen numre derimot, dekker over fragmenter fra forskjellige håndskrifter. De samlingene som håndskriftsaken angikk, bestod heller ikke bare av middelalderske pergament- 
håndskrifter, men inneholdt også mange papirhåndskrifter fra tida etter reformasjonen. Men største delen av disse papirhåndskriftene er avskrifter av eldre håndskrifter med middelalderske tekster. De bevarer i mange tilfeller tekster eller tekstredaksjoner som ellers er tapt, og har da nesten like stor vitenskapelig betydning som membranene fra middelalderen.

Når vi ser bort fra de unøyaktighetene som kommer av at et håndskriftnummer ikke alltid refererer til ett håndskrift som fra begynnelsen av har vært én bok, kan tall allikevel si oss en hel del om omfanget av det vi snakker om, og om proporsjoner.

Det materiale som ble avlevert til Island etter håndskriftsaken i årene 1971 til 1997 var følgende:

Fra Den arnamagnæanske samling: 1666 numre

Fra Det Kongelige bibliotek: 141 numre

Originaldiplomer $\quad 1345$

Avskrifter av diplomer $\quad 5942$

Det er en utbredt misforståelse, også i Danmark, at Island fikk alle de islandske håndskriftene. Slik var det ikke. I den arnamagnæanske samling i København ble det igjen 1350 håndskrifter, men bare omtrent halvdelen er islandske. En del islandske håndskrifter i Det Kongelige bibliotek, som opprinnelig tilhørte privatsamlinger, ble også igjen der. Dessuten er det også mange islandske håndskrifter i Sverige, både fra middelalderen og senere og noen, som regel ganske unge, i Norge. Dessuten finnes det islandske håndskrifter med middelalderstoff (deriblant noen få fra middelalderen) i Tyskland, Nederland, Storbritannia, Irland, USA og Kanada.

Etter denne innledningen skal jeg komme til mitt emne: hvilken vitenskapelig betydning har de islandske håndskriftenes hjemkomst hatt og vil ha? Og hva slags ideologiske implikasjoner har hele saken hatt?

Allerede mens håndskriftfeiden pågikk kunne forskere i de aller fleste tilfeller bruke fotografier med like gode resultater som ved bruk av håndskriftene selv. Det gjør man også helst for å unngå slitasje av originalene. Når vi nå holder på å lage digitale bilder med høy oppløsning, som kan sendes mellom kontinenter med lynfart, blir det enda klarere at et håndskrifts plassering i det ene eller det andre landet ikke kan være en alvorlig hindring for forskningen, så lenge de materielle betingelser, sikkerhet, kommunikasjon, hjelpemidler etc., er i orden. Riktignok er det tilfeller, spesielt når det gjelder palaeografiske, kodikologiske eller kunsthistoriske studier, hvor tilgang til selve originalen er nødvendig. Men slike problemer kan lett løses ved reisestipender, lån av manuskripter (hvis det gjeldende håndskrift i det hele tatt lånes ut fra en institusjon til en annen), etc. Allikevel har hensynet til vitenskapen spilt en stor rolle i debatten, og det med rette. Det er to viktige grunner til dette. Den ene har med forskningsmiljø å gjøre, den andre med forskningspolitikk.

Det er ikke nødvendig å fortelle museumsfolk at de originale og unike, konkrete objektene alltid har en helt annen effekt på den som opplever dem direkte med sine sanser enn en etterligning eller kopi, enten den er materiell eller virtuell, og hvor god den ellers måtte være. Det er som om tingene har en aura som tekniske etterligninger aldri kan erstatte. Dette er vel en av grunnene til at forskere fra hele verden, som forsker $\mathrm{i}$ islandsk og nordisk middelalderlitteratur, gjerne vil komme og drive sin forskning ved de arnamagnæanske instituttene, enten i København eller Reykjavík, selv om de på langt nær alltid trenger å gå til selve håndskriftene. Dette kommer 
selvsagt av at vi ved disse instituttene har gode betingelser, spesialbiblioteker, fotografier og andre hjelpemidler, men naturligvis også en gruppe mennesker som med sin samlede ekspertise bilder en slags kritisk masse på dette feltet. Her tenker jeg selvsagt ikke bare på de fast ansatte ved instituttene, men også på gjesteforskere, stipendiater og studenter som til enhver tid arbeider der. Begge steder nyter man også godt av å høre til et universitetsmiljø - som er sterkt på dette område - og nærheten til store nasjonale biblioteker. I Reykjavík er det spesielt viktig at vi på fem minutters avstand (til fots) har Nasjonal- og universitetsbiblioteket (Landsbókasafn Íslands - Háskólabókasafn), som ikke bare skal ha alle islandske bøker og bøker om islandske forhold, men også oppbevarer den aller største samlingen av islandske håndskrifter som finnes. De fleste av disse er papirhåndskrifter fra tida etter reformasjonen, men mange av dem inneholder middelalderlitteratur; de samme verkene som vi finner $\mathrm{i}$ våre håndskrifter fra middelalderen. Jeg kunne også nevne både Nasjonalarkivet (pjódskjalasafn) og Nasjonalmuseet (pjódminjasafn), og det skulle være unødvendig å argumentere for den konklusjon at Reykjavík er det beste stedet for å forske $\mathrm{i}$ islandsk litteratur og andre særislandske saker. Dernest følger København, Islands hovedstad gjennom århundrer. Når man sammenligner betingelsene i Reykjavík med København eller andre steder, må man også ta i betraktning et meget viktig moment, og det er mulighetene til forskerrekruttering. Det er åpenbart og kan også statistisk påvises at de er helt andre på Island, hvor studiet av den islandske kultur er et sentralt anliggende, enn $\mathrm{i}$ andre land. Dette tror jeg kommer til å være tilfelle $\mathrm{i}$ overskuelig framtid, uansett hvilke tekniske framskritt vi kommer å oppleve, også om vi tar i betraktning forandrede holdninger hos generasjoner som er vokst opp med oppmerksomheten like mye vendt mot den virtuelle virkelighet som den 'virkelige'.

Dette bringer oss inn på de ideologiske faktorer som influerer såvel forskningspolitikk som rekruttering. Men før jeg begynner med dette aspektet, vil jeg kort si, at jeg ikke på noen måte bebreider de forskere og museumsfolk i Danmark som i sin tid sterkt motsatte seg utleveringen av håndskriftene til Island. Det ser jeg som en naturlig reaksjon. Selv om noen forskere ved Islands universitet hadde markert seg med en klar profil på dette området i første halvdel av det tyvende århundre, var det vanskelig for danske vitenskapsfolk, som var vant til å gjøre strenge krav til kvalitet, såvel i selve forskningen som til forskningbetingelser som biblioteker, å skjønne den sterke utviklingen som alt da var igang i det islandske samfunnet, for ikke å snakke om den lynraske utviklingen som siden har foregått. Man må også ta i betraktning at ikke bare islendingene var påvirket av nasjonalistisk ideologi, eller skal jeg si patriotisme; det gjaldt også danskene. Man skal heller ikke glemme at Islands metode for å frigjøre seg endelig fra Danmark i 1944, mens Danmark var besatt, ikke hadde møtt mye forståelse eller sympati i Danmark. Allikevel fikk håndskriftsaken den avslutning den fikk med støtte fra det politiske flertall og vel også fra store deler av den danske allmennhet.

Hele debatten hadde den velgjørende effekt på forskningpolitikken at den offentlige oppmerksomheten ble rettet mot de skatte som man hadde $\mathrm{i}$ håndskriftsamlingene, og det ble reist spørsmål om hvor de beste betingelsene var for å utforske dem. Både ved Københavns universitet og ved Islands universitet brukte man anledningen til å få politisk 
støtte til finansering av forskning på området. I Danmark ble Det Arnamagnæanske institut opprettet i 1957 under ledelse av islendingen Jón Helgason som ivrig hadde kjempet for å få det til. Islands universitet hadde allerede i 1955 satt i gang et tekstfilologisk utgivelsesprosjekt, og i 1962 ble Handritastofnun Íslands (Det islandske håndskriftinstitutt) opprettet; som etter at håndskriftsaken var løst og de første håndskrifter avlevert, ved lov av 1972 fikk navnet Stofnun Árna Magnússonar á Íslandi. Disse to instituttene ville aldri blitt opprettet med så gode arbeidsbetingelser og så mange vitenskapelige ansatte, hvis ikke det hadde blitt en prestisjesak, både for Island og Danmark, mens saken var under debatt og behandling, å vise at man ville og kunne drive intensiv forskning av høy internasjonal standard i håndskriftene og den kulturarv som de er del av.

Håndskrifter er bøker, og islendingene var i middelalderen et bokproduserende og et boklesende folk (naturligvis var det bare et lite mindretall som kunne lese, selv om det er overensstemmelse i kildene om at lesekyndigheten var relativt høy), men mange fler fikk høre opplesning fra bøker. Bøker var derfor bruksgjenstander. Man kan se av bøker som Codex regius av eddadiktene eller sagahåndskrifter som Mödruvallabók, at de er laget for bruk, for opplesning, og ikke som kunstgjenstander eller statussymboler. Andre bøker uttrykker klart enten kirkens store makt og status i samfunnet, samt respekt for dens budskap, eller overklassens makt og velde (lovbøker som Skardsbók og kongesagahåndskrifter som Flateyjarbók).

1500-tallet brakte store kulturelle omveltninger: reformasjonen med økt kongemakt, trykkerier og papir. De gamle middelalderhåndskriftene var blitt vanskelige å lese, og pergamenthåndskrifter var dyre å produsere. Det var konkurranse med ny, religiøs, trykt litteratur. Riktignok hadde kirken monopol på trykkeriet og var ikke interessert i gamle verdslige sagaer eller dikt, heller ikke papistisk litteratur som helgensagaer. Man fortsatte med å skrive på pergament ved siden av papir til begynnelsen av 1600-tallet, men det er klart at de gamle skinnbøkene holdt på å tape sin verdi, og stod derfor i fare for å gå tapt. Interessen for sagaer og kvad holdt seg allikevel, både hos lek og lærd, som en mengde papiravskrifter viser.

Det var humanismen som ble redningen. Lærde folk i Skandinavia fikk interesse for de islandske håndskriftene, fordi de fant ut at der var det fortellinger om Nordens ærefulle fortid. Høytstående personer i Danmark og Sverige begynte å samle islandske håndskrifter og lærde professorer ansatte islandske studenter til å lese, skrive av og oversette. Dette var viktig for den islandske selvbevissthet. Det gikk mer eller mindre grunnløse skrøner om landet blant forfattere av reiseskildringer, og dets største krav på attraksjon var at det her skulle finnes selve porten til Helvete, Hekkenfeld, dvs. vulkanen Hekla. Litteraturen ble nå det sterkeste våpen til forsvar av landets rykte. Med moderne språkbruk kan man si at landets PR-folk brukte den til å skape et nytt og positivt 'image' av landet. Denne funksjonen har litteraturen hatt inn i det allersiste, til nå når Björk og Sigurrós og andre popgrupper har slått ut sagaene og Laxness som landets kulturelle front.

1600- og 1700-tallet brakte utgaver, först med oversettelser til latin, senere også til folkespråkene. I før-romantikkens og senere nasjonalromantikkens tid ble det stor interesse både i Tyskland, Storbritannia og Skandinavia, først for mytologi og eddadikt og senere 
også for sagaer, spesielt islendingesagaer. Denne store interessen for den litteraturen som islendingene var alene om å kunne lese på sitt morsmål, og som dessuten beskrev en islandsk heltetid, en gullalder slik mange så det, hadde enorm betydning for islendingenes selvbevissthet under den selvstendighetskampen som begynte noe før midten av 1800-tallet og sluttet med republikkens grunnleggelse 1944. Dette er da bakgrunnen for de sterke følelsene som håndskriftsaken vekket. Håndskriftene var de synlige manifestasjonene av den fortid som berettiget islendingene til å bli en selvstendig nasjon som tok ansvar for seg selv og sin kultur. Etter at landet var blitt fritt og selvstendig, kjente folk det som en stor urettferdighet at disse skattene skulle ha blitt igjen i det land som tidligere hersket over dem.

Men motstanden hadde også sin ideologiske bakgrunn. Tyske og nordiske forskere hadde helt fra de oppdaget den gamle islandske litteraturen, lagt vekt på at den representerte gammel germansk, 'altgermanisch', gammelnordisk, oldnordisk, götisk eller gammelnorsk kultur. Dette gjaldt selvfølgelig spesielt mytologi og heltediktning, men også kongesagaer og fornaldarsagaer, som jo handler om nordiske konger og helter. Til og med islendingesagaene, som unektelig måtte være islandske, ble sett som eksempler på germansk ånd. Grundtvig hadde selvfølgelig stor betydning for den allmenne kjennskapen til den gamle islandske litteraturen i Danmark, og den nasjonalistiske bevegelse i Norge etter 1814 gjorde Snorris kongesagaer til en slags verdslig bibel for det norske folk.

Det var derfor ikke noen selvfølge for folk i Norden at de islandske håndskriftene, som ble oppbevart i de kongelige samlingene og universitetsbiblioteker, skulle tilbake til opphavslandet Island. Resultatet av det hele, den

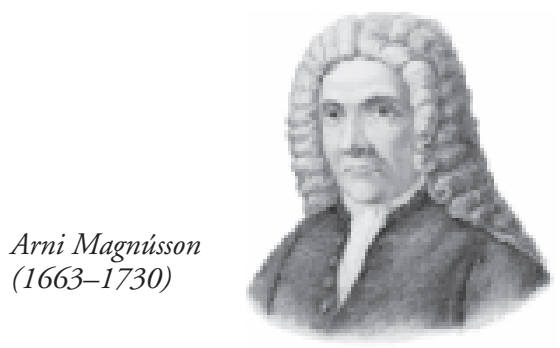

oppdeling som i praksis ble gjort, gjenspeiler i noen grad disse to ideologiske holdningene. Vi har hørt at Island skulle få det som var islandsk kultureie, det var da implisitt at sagaer om nordiske konger, selv om de var skrevet av islendinger, ikke skulle utleveres, heller ikke europeisk litteratur i oversettelse og en del annet.

Ønsket om å få håndskriftene hjem igjen hadde $\mathrm{i}$ sin tid en enormt sterk gjenklang $\mathrm{i}$ det islandske folk. Det viste seg også da de to første bøkene, Codex regius av eddadiktene og Flateyjarbók ble brakt iland i Reykjavík havn, og samme dag av den danske undervisningsminister lagt $\mathrm{i}$ hendene på hans islandske kollega. Jeg vil også tro at saken har hatt stor innflytelse i Danmark. Det var en storsinnet gjerning som jeg tror meget få angrer i Danmark i dag. Saken gjelder meget mer enn de ca. 1800 håndskrifter som nå oppbevares $i$ Stofnun Árna Magnússonar í Reykjavík. Den dreier seg også om kulturbevissthet, om gjensidig respekt og forståelse mellom folk og om rettferdighet. Det er en glede når man får høre om flere tilfeller av lignende utleveringer. Jeg tror at det århundret som så vidt har begynt vil se mange slike.

\section{Professor Vésteinn Ólason är chef för Islands Arnemagnaanske Institut. \\ Adr. Stofnun Árna Magnússonar à Íslandi, Árnagardi vid Sudurgötu, IS-101 Reykjavík E-mail:vesteinn@hi.is}

